\title{
Responsabilidade Civil do Residente em Medicina: Jurisprudência do Estado de São Paulo
}

\author{
Civil Responsibility of the Medical Resident: \\ Jurisprudence in the State of São Paulo
}

\author{
Ana Tomie Nakayama Kurauchi', Mônica Vieira da Motta Piacsek², \\ Márcia Vieira da Motta ${ }^{3}$
}

DOI: http://dx.doi.org/10.11606/issn.2317-2770.v22i1p26-40

\begin{abstract}
Kurauchi ATN, Piacsek MVM, Motta MV. Responsabilidade Civil do Residente em Medicina: Jurisprudência do Estado de São Paulo. Saúde, Ética \& Justiça. 2017;22(1):26-40.

RESUMO: O médico residente, por ser profissional já graduado, responde a ações de responsabilidade civil em conformidade à legislação civilista ou consumerista de acordo com o âmbito do serviço prestado, se público ou privado, respectivamente. Este trabalho levantou a jurisprudência do Tribunal de Justiça de São Paulo em que residentes atuaram no polo passivo de lides sobre erro médico no estado de São Paulo, entre janeiro de 1998 e dezembro de 2016. As decisões indicaram que nas ações em que o residente respondeu com superiores hierárquicos acadêmicos eles não tiveram sua culpa apreciada e, sim, a dos seus supervisores, exceto em casos de erro grosseiro. Quando participaram do feito junto à equipe do hospital, sem que houvesse vinculação acadêmica, foram condenados em todas as ações, mediante verificação de culpa pessoal sobre o dano. Nas lides em que responderam sozinhos apenas com o hospital, foram condenados em apenas 2 casos $(14,3 \%)$. Muito embora várias das instituições privadas que compuseram a amostra fossem prestadoras de serviço público, tanto seus médicos quanto os residentes não deveriam ter participado das lides por terem atuado como agentes públicos, porém a ilegitimidade não foi suscitada nas ações tempestivamente. O dever do médico de prover informação aos pacientes mereceu destaque nos acórdãos, já que a conduta esclarece quais procedimentos serão realizados e seus possíveis efeitos adversos. A falta de documentação neste sentido pode suscitar o entendimento de que houve dano indenizável pelos magistrados.
\end{abstract}

DESCRITORES: Internato e Residência/LJ; Erros Médicos; Defesa do Consumidor; Direito Administrativo; Imperícia; Jurisprudência; Responsabilidade Legal; Responsabilidade Civil.

\footnotetext{
1. Médica Pediatra doutoranda da Faculdade de Medicina da Universidade de São Paulo. ana.kurauchi@usp.br

2. Advogada e Mestre em Administração.monica.piacsek@gmail.com

3. Advogada e Professora do Curso de Especialização em Medicina Legal da USP-SP.

Endereço para correspondência: Márcia Vieira da Motta. Rua Jesuíno Arruda, 676, Itaim, São Paulo, SP. E-mail: marcia.motta@ gmail.com
} 


\section{INTRODUÇÃO}

$\mathbf{S}$ egundo Gomes e França, “erro médico é o dano provocado no paciente pela ação ou inação do médico, no exercício da profissão, e sem a intenção de cometê-lo. Há três possibilidades de suscitar o dano e alcançar o erro: imprudência, imperícia e negligência" ${ }^{1}$ "No sentido mais amplo, podem-se incluir neste conceito os erros em técnica ou em procedimentos de qualquer profissional de saúde envolvido na assistência de pacientes.

$\mathrm{Na}$ atualidade e no contexto brasileiro, o médico assume obrigação de meio para com o paciente, ou seja, compromete-se a agir diligentemente para alcançar os resultados esperados no seu diagnóstico, tratamento ou reabilitação. Todavia, resultados adversos ao esperado ou, ainda, acidentes imprevisíveis podem ocorrer ao longo do tratamento, sendo exceções expostas pela mídia como se comum fossem. O forte apelo comercial da notícia jornalística relega a verdade dos fatos a um segundo momento, não se preocupando com o impacto social criado pelo sensacionalismo na ilustração de matérias relacionadas a má prática profissional ${ }^{2}$. De fato, a maioria das intercorrências não produz consequências perceptíveis aos pacientes. São eventos usualmente inesperados e imprevistos que se sucedem no decorrer do procedimento, independentes do atuar médico. Mesmo que produzam dano, não há o dever de indenização pelo profissional. Em alguns casos esses eventos são até previsíveis, porém fogem do controle do profissional. Também não há o dever de indenizar nos casos de iatrogenia (latu senso), em que o dano é causado pela correta atuação profissional ${ }^{3}$ :

A iatrogenia, quando consequência natural e inevitável
do tratamento médico dispensado pelo médico, não tem
o condão de gerar obrigação do profissional que obrou
com o zelo e a perícia atinentes ao caso, pois se assim
o fizer, estar-se-ia colocando-o na posição de segurador
universal, o que não é aceito no ordenamento jurídico
pátrio.

Do ponto de vista legal, a má prática do profissional da área da saúde pode ser enquadrada no âmbito da justiça comum e no âmbito administrativo, frente aos conselhos de classe. A responsabilidade civil a ela atrelada, é "dever jurídico sucessivo que surge para recompor o dano decorrente da violação de um dever jurídico originário"4. Este dano é ressarcível, ainda que de ordem exclusivamente moral conforme prescrito nos arts. 186 e 927 do Código Civil ${ }^{5}$ :

Art. 186. Aquele que, por ação ou omissão voluntária, negligência ou imprudência, violar direito e causar dano a outrem, ainda que exclusivamente moral, comete ato ilícito.

Art. 927. Aquele que, por ato ilícito (arts. 186 e 187), causar dano a outrem, fica obrigado a repará-lo.
Mas o que seriam deveres jurídicos originários e sucessivos e qual a importância deste entendimento?

O dever jurídico originário é aquele que nasce da relação que se estabelece entre as partes, ou seja, se contratual ou extracontratual (legal). Versa sobre a obrigação assumida entre partes. Já o dever jurídico sucessivo decorre desta relação e avalia como será apurada a responsabilidade, se subjetiva ou objetiva, respectivamente com apreciação ou não da culpa do autor da conduta.

No exercício profissional do médico, a relação que se estabelece com o paciente usualmente é contratual, mesmo que o contrato seja tácito, e o dever jurídico que surge da violação do contrato é o da responsabilidade civil subjetiva, por força da lei. Isto porque, tanto o Código Civil $^{5}$ quanto o Código de Defesa do Consumidor ${ }^{6}$ estabelecem que a responsabilidade dos profissionais, em geral $^{5}$, e dos profissionais liberais ${ }^{6}$ será apurada mediante verificação da culpa:

Art. 951. O disposto nos arts. 948, 949 e 950 aplicase ainda no caso de indenização devida por aquele que, no exercício de atividade profissional, por negligência, imprudência ou imperícia, causar a morte do paciente, agravar-lhe o mal, causar-lhe lesão, ou inabilitá-lo para o trabalho ${ }^{5}$. Grifa-se.

Art. 14. O fornecedor de serviços responde, independentemente da existência de culpa, pela reparação dos danos causados aos consumidores por defeitos relativos à prestação dos serviços, bem como por informações insuficientes ou inadequadas sobre sua fruição e riscos. $\S 4^{\circ}$ A responsabilidade pessoal dos profissionais liberais será apurada mediante a verificação de culpa ${ }^{6}$. Grifa-se.

Assim, mesmo que os contratos versem sobre obrigações que originalmente seriam de resultado, a responsabilidade que delas surge permanecerá apreciada de acordo com a responsabilidade subjetiva, ou seja, mediante a apreciação da culpa. Este é o entendimento jurisprudencial ${ }^{7}$ :

RESPONSABILIDADE CIVIL. ERRO MÉDICO. ART. 14 DO CDC. CIRURGIA PLÁSTICA. OBRIGAÇÃO DE RESULTADO. CASO FORTUITO. EXCLUDENTE DE RESPONSABILIDADE.

1. Os procedimentos cirúrgicos de fins meramente estéticos caracterizam verdadeira obrigação de resultado, pois neles o cirurgião assume verdadeiro compromisso pelo efeito embelezador prometido.

2. Nas obrigações de resultado, a responsabilidade do profissional da medicina permanece subjetiva. Cumpre ao médico, contudo, demonstrar que os eventos danosos decorreram de fatores externos e alheios à sua atuação durante a cirurgia. [...]Grifa-se.

Neste cenário, associado à deficiência na formação 
acadêmica e humanística dos novos profissionais ${ }^{8}$, especula-se que os médicos com maior predisposição a causar danos ressarcíveis seriam os menos experientes, principalmente os que estão nos primeiros anos de treinamento, independentemente da especialidade. Sempre que há a introdução de uma nova tecnologia ou quando se avaliam os profissionais em sua fase inicial de treinamento, como, por exemplo, no início da residência, seria esperada uma frequência maior de intercorrências que poderiam ser interpretadas como má prática.

Como o médico residente está em treinamento, conforme prescrito na lei $\mathrm{n}^{\circ} 6.932^{9}$, estaria ele, em ações de responsabilidade civil, mais predisposto a ter sua culpa avaliada pelo âmbito da imperícia, já que está cursando esta modalidade de ensino exatamente porque quer aprimorar sua competência na área?

Nestes casos, de acordo com a Resolução Conselho Nacional de Residência Médica $n^{\circ} 4$ de $1978^{10}$, estes profissionais deveriam estar sob supervisão permanente, de modo que seus erros refletiriam legalmente na responsabilidade do médico supervisor. Todavia, sua responsabilidade não seria escusada, já que até mesmo a autarquia entende que "não há como isentar os médicos residentes da responsabilidade jurídica por eventuais danos, uma vez caracterizada a prática do ato ilícito""11.

Deste modo, o objetivo deste trabalho foi buscar, junto ao Tribunal de Justiça de São Paulo (TJSP) ${ }^{12}$, o entendimento trazido pelos acórdãos do órgão quanto à responsabilidade civil que o Tribunal paulista atribui ao médico residente nestes casos.

\section{MÉTODO}

Foi realizada busca ativa de acórdãos no instrumento de consulta completa do site do TJSP ${ }^{12}$ por meio da combinação das seguintes palavras-chaves: "médico", "residente", "responsabilidade civil" e "erro médico". O período estudado abrangeu os julgados entre $01 / 01 / 1998$ e 31/12/2016. Os acórdãos foram lidos na íntegra para que o pesquisador pudesse avaliar sua pertinência à matéria estudada. Foram excluídos: casos exclusivamente penais, casos em que a palavra residente era apenas citada na jurisprudência trazida nos acórdãos, casos em que a conduta do residente foi mencionada, porém este não fez parte da lide, ou casos sem relevância direta ao entendimento da responsabilidade civil. Depois de recuperada a jurisprudência frente aos parâmetros mencionados, quando o residente não figurava no polo passivo ou ativo do recurso que ensejou o acórdão, buscou-se no instrumento de consulta de processos em primeira instância do $\operatorname{TJSP}^{13}$ sua figuração como parte da lide em momento processual antecedente. Quando possível, recuperaram-se informações da sentença da lide principal para que se pudesse esclarecer a situação fática e melhor esclarecer sua participação no feito.

Os resultados foram organizados em tabelas e gráficos contendo: número do processo no Tribunal de Justiça de São Paulo, especialidade, médicos envolvidos, conduta lesiva, fato motivador da lide e decisão do tribunal. A especialidade foi referida conforme textualmente descrito na decisão, ou de acordo com o procedimento executado. Também se buscou junto ao portal do Conselho Federal de Medicina (CFM) ${ }^{14}$ o registro da especialidade dos profissionais envolvidos. $\mathrm{O}$ registro dos programas de residência foi encontrado nos sites institucionais dos hospitais envolvidos.

Como a natureza do atendimento, se pública ou privada, usualmente não foi referida nos acórdãos, também se recorreu aos sites institucionais das entidades em que o dano ocorreu, para recuperar a informação se estas realizavam atendimento exclusivamente particular, por convênios ou pelo Sistema Único de Saúde (SUS) de modo a caracterizar se poderiam ser pessoas jurídicas de direito privado prestadoras de serviço público conforme art. $37, \S 6^{\circ}$ da Constituição Federal ${ }^{15}$. Quando possível, os dados foram agrupados de acordo com as variáveis acima descritas e expressos em termos de porcentagem.

As discussões foram baseadas na legislação mencionada nos acórdãos, obtidas diretamente do acervo oficial do sítio do planalto (http://www2.planalto.gov.br/ acervo/legislacao), na normativa do Conselho Federal de Medicina e na literatura mencionada nos acórdãos.

\section{RESULTADOS}

Foram encontrados 85 acórdãos no TJSP no período estudado, tratando de decisões envolvendo erro médico, com menção ao residente médico no seu inteiro teor. Destes, foi possível determinar 29 lides em que o residente figurou no polo passivo ou que foi chamado para compô-lo, pelo menos em instância inferior ${ }^{16-}$ 56. Os dados foram organizados nas Tabelas 1A e 1B. A nomenclatura nos acórdãos parece diferenciar estagiários de residentes, muito embora ambos estejam sob treinamento. Todavia, foram excluídos da amostra acórdãos em que se mencionavam médicos em treinamento sem que houvesse indicação de participação em programa de residência. Quanto ao responsável pela supervisão ou pelo serviço prestado, a terminologia variou bastante entre as decisões de modo que foram todas incluídas: "professor", "chefe", "especialista" ou "preceptor". Como especialista incluiu-se o médico plantonista. 
Kurauchi ATN et al. Responsabilidade Civil do Residente em Medicina: Jurisprudência do Estado de São Paulo.

Tabela 1A. Processos de responsabilidade civil envolvendo médicos residentes no TJSP no período de 01/01/1998 e 15/11/2016, $\mathrm{n}=29$

\begin{tabular}{|c|c|c|c|c|c|c|c|c|c|c|c|c|}
\hline \multirow[b]{2}{*}{$\begin{array}{l}\text { NÚMERO DOS PROCESSOS } \\
\text { LIGADOS À LIDE }\end{array}$} & \multirow[b]{2}{*}{ 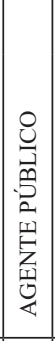 } & \multirow[b]{2}{*}{$\overbrace{\infty}^{n}$} & \multirow[b]{2}{*}{ 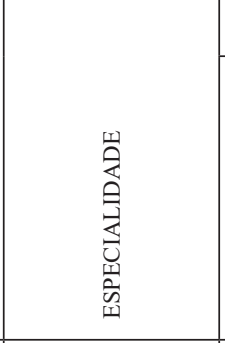 } & \multicolumn{5}{|c|}{ RÉUS } & \multirow[b]{2}{*}{$\begin{array}{l}\text { MOTIVO DA LIDE CONFORME } \\
\text { DESCRITO NA DECISAO } \\
\text { (MODALIDADE DE CULPA) }\end{array}$} & \multicolumn{2}{|c|}{ RESULTADO } & \multirow[b]{2}{*}{ DATA } \\
\hline & & & & 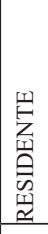 & 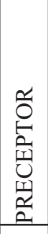 & 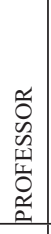 & 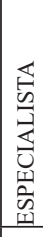 & 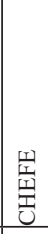 & & 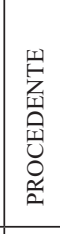 & 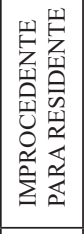 & \\
\hline $9038651-22.1998 .8 .26 .0000^{16}$ & $\mathrm{~S}$ & $\mathrm{~S}$ & Urologia & $\mathrm{x}$ & & & & & $\begin{array}{l}\text { Reversão de vasectomia } \\
\text { (SEM CULPA) }\end{array}$ & & $\mathrm{x}$ & $24 / 10 / 2000$ \\
\hline $9092473-86.1999 .8 .26 .0000^{17}$ & $\mathrm{~N}$ & $\mathrm{~N}$ & Pediatria & $\mathrm{x}$ & & & $\mathrm{x}$ & & $\begin{array}{l}\text { Amputação de perna. Retardo no diagnóstico } \\
\text { (NEGLIGÊNCIA E IMPERÍCIA) }\end{array}$ & $x$ & & $29 / 05 / 2003$ \\
\hline $9171717-30.2000 .8 \cdot 26.0000^{18}$ & $\mathrm{~S}$ & $\mathrm{~S}$ & Oftalmologia & $\mathrm{x}$ & & & & & $\begin{array}{l}\text { Complicaçoes de ciclocrioterapia. } \\
\text { (SEM CULPA) }\end{array}$ & & $\mathrm{x}$ & $19 / 05 / 2005$ \\
\hline $9196967-65.2000 .8 .26 .0000^{19}$ & ? & $\mathrm{s}$ & Neurologia & $\mathrm{x}$ & $\mathrm{X}$ & & & & $\begin{array}{l}\text { Cirurgia de Hérnia Discal. Lesões. } \\
\text { (CULPA) }\end{array}$ & $\mathrm{x}$ & $\mathrm{X}$ & $13 / 09 / 2005$ \\
\hline $9166914-33.2002 .8 \cdot 26.0000^{20,21}$ & $?$ & $\mathrm{~s}$ & Cirurgia* & $\mathrm{x}$ & & $\mathrm{x}$ & & & $\begin{array}{l}\text { Esquecimento de gaze. Colicistite aguda. } \\
\text { (IMPRUDÊNCIA) }\end{array}$ & $\mathrm{x}$ & $\mathrm{x}$ & $\begin{array}{l}28 / 04 / 2006 \\
23 / 06 / 2008\end{array}$ \\
\hline $9104886-29.2002 .8 \cdot 26.0000^{22}$ & $?$ & S & $\begin{array}{l}\text { Ginecologia e } \\
\text { Obstetrícia }\end{array}$ & $\mathrm{x}$ & & & & $\mathrm{X}$ & $\begin{array}{c}\text { Síndrome da aspiração de mecônio. Morte } \\
\text { recém-nascido. Plantão à distância. } \\
\text { (NEGLIGÊNCIA e IMPERÍCIA/EMENTA; } \\
\text { em IMPRUDÊNCIA/INTEIRO TEOR) }\end{array}$ & $\mathrm{x}$ & & $30 / 11 / 2006$ \\
\hline $9219792-32.2002 .8 \cdot 26.0000^{23}$ & $?$ & S & Anestesiologia & $\mathrm{x}$ & & & & $\mathrm{X}$ & $\begin{array}{c}\text { Artroscopia do joelho. Danos neurológicos - } \\
\text { ato anestésico. } \\
\text { (NEGLIGÊNCIA) }\end{array}$ & $\mathrm{x}$ & & $19 / 06 / 2007$ \\
\hline $9156055-84.2004 .8 .26 .0000^{24}$ & $\mathrm{~S}$ & S & $\begin{array}{l}\text { Ginecologia e } \\
\text { Obstetrícia }\end{array}$ & $\mathrm{x}$ & & & & & $\begin{array}{l}\text { Cirurgia laqueadura. Perfuração intestinal. } \\
\text { (IMPERÍCIA) }\end{array}$ & $\mathrm{x}$ & & $16 / 07 / 2007$ \\
\hline $9193021-17.2002 .8 \cdot 26.0000^{25}$ & $?$ & S & $\begin{array}{l}\text { Ortopedia e } \\
\text { Traumatologia }\end{array}$ & $\mathrm{x}$ & & & & $\mathrm{x}$ & $\begin{array}{l}\text { Fratura. Retardo diagnóstico. Necrose. } \\
\text { Amputação. } \\
\text { (NEGLIGÊNCIA, IMPRUDÊNCIA E } \\
\text { IMPERÍCIA/escolha de técnica) } \\
\end{array}$ & $\mathrm{x}$ & & $17 / 01 / 2008$ \\
\hline $9196454-29.2002 .8 \cdot 26.0000^{26}$ & $?$ & S & $\begin{array}{l}\text { Ginecologia e } \\
\text { Obstetrícia }\end{array}$ & $\mathrm{x}$ & & & & & $\begin{array}{c}\text { Parto. Lesão de reto. Não emprego de } \\
\text { melhor técnica para tratamento. Inércia } \\
\text { autor. Residente não compôs polo passivo. } \\
\text { (NEGLIGENCIA) }\end{array}$ & $\mathrm{x}$ & & $01 / 12 / 2010$ \\
\hline $\begin{array}{l}0201825-74.2009 .8 \cdot 26.0100^{27} \\
0201822-22.2009 .8 \cdot 26.0100^{28}\end{array}$ & $?$ & S & Cirurgia* & $\mathrm{x}$ & & & & & $\begin{array}{l}\text { Histerectomia. Evolução quadro infeccioso. } \\
\text { Diagnóstico tardio. } \\
\text { (SEM NEXO) }\end{array}$ & & $\mathrm{x}$ & $\begin{array}{l}26 / 05 / 2011 \\
15 / 09 / 2011\end{array}$ \\
\hline $\begin{array}{l}0050924-50.2003 .8 .26 .0506^{29} \\
9187357-92.2008 .8 .26 .0000^{30}\end{array}$ & $?$ & $\mathrm{~S}$ & $\begin{array}{l}\text { Ortopedia e } \\
\text { Traumatologia }\end{array}$ & $\mathrm{x}$ & & & & & $\begin{array}{c}\text { Acidente moto. Fratura de clavícula. } \\
\text { Diagnóstico tardio. Residente chamado a } \\
\text { lide - indeferimento. } \\
\text { (CULPA) }\end{array}$ & $\mathrm{x}$ & $\mathrm{x}$ & $\begin{array}{l}28 / 01 / 2008 \\
31 / 01 / 2012\end{array}$ \\
\hline $0010653-28.2007 .8 .26 .0451^{31}$ & $\mathrm{~N}$ & - & Cirurgia Plástica & $\mathrm{x}$ & & & $\mathrm{x}$ & & $\begin{array}{l}\text { Panturrilha. Plástica. Cicatrizes visíveis. } \\
\text { (CULPA) }\end{array}$ & $\mathrm{x}$ & & $24 / 04 / 2012$ \\
\hline $9032583-70.2009 .8 .26 .0000^{32}$ & $\mathrm{~S}$ & $\mathrm{~S}$ & Otorrinolaringologia & $\mathrm{X}$ & & $\mathrm{x}$ & & & $\begin{array}{l}\text { Polipose nasal. Cirurgia. Cegueira. } \\
\text { (SEM CULPA) }\end{array}$ & & $\mathrm{x}$ & $9 / 05 / 2012$ \\
\hline
\end{tabular}

*sem especificação da área cirúrgica. ** especialidade do residente. ? não relatado. S = sim. $\mathrm{N}=$ não. 
Kurauchi ATN et al. Responsabilidade Civil do Residente em Medicina: Jurisprudência do Estado de São Paulo.

Tabela 1B. Processos de responsabilidade civil envolvendo médicos residentes no TJSP no período de 01/01/1998 e 15/11/2016, $\mathrm{n}=29$

\begin{tabular}{|c|c|c|c|c|c|c|c|c|c|c|c|}
\hline \multirow[b]{2}{*}{$\begin{array}{l}\text { NÚMERO DOS } \\
\text { PROCESSOS } \\
\text { LIGADOS À LIDE }\end{array}$} & \multirow[b]{2}{*}{ 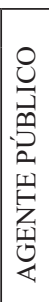 } & \multirow[b]{2}{*}{$\overbrace{2}^{2}$} & \multirow[b]{2}{*}{ 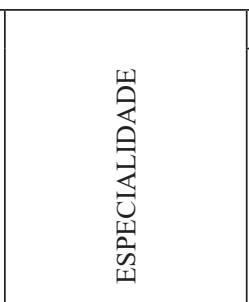 } & \multicolumn{4}{|c|}{ RÉUS } & \multirow[b]{2}{*}{$\begin{array}{c}\text { MOTIVO DA LIDE } \\
\text { CONFORME DESCRITO NA } \\
\text { DECISAO } \\
\text { (MODALIDADE DE CULPA) }\end{array}$} & \multicolumn{2}{|c|}{ RESULTADO } & \multirow[b]{2}{*}{ DATA } \\
\hline & & & & 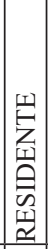 & 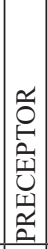 & 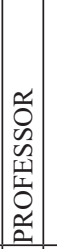 & 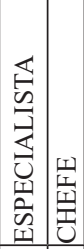 & & 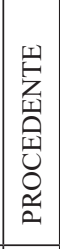 & 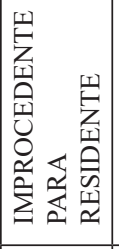 & \\
\hline $0056747-30.2001 .8 .26 .0100^{33}$ & $\mathrm{~N}$ & $\mathrm{~N}$ & Otorrinolaringologia & $\mathrm{X}$ & & & $\mathrm{X}$ & $\begin{array}{l}\text { Cirurgia da adenoide. } \\
\text { Hemorragia. Parada } \\
\text { cardiorrespiratória. Morte. } \\
\text { (NEGLIGÊNCIA) }\end{array}$ & $\mathrm{X}$ & & $23 / 05 / 2012$ \\
\hline 0011441-26.2005.8.26.0576 & $?$ & S & Anestesiologia & $\mathrm{X}$ & & $\mathrm{x}$ & & $\begin{array}{l}\text { Cirurgia urológica. Acidente } \\
\text { anestésico. Paraplegia. } \\
\text { (NEGLIGÊNCIA/anestesista) }\end{array}$ & $\mathrm{X}$ & $\mathrm{X}$ & $3 / 10 / 2012$ \\
\hline $\begin{array}{l}0107546-03.2012 .8 .26 .0000^{35} \\
0008492-52.2011 .8 .26 .0565^{36}\end{array}$ & S & $\mathrm{S}$ & $\begin{array}{l}\text { Hematologia e } \\
\text { Hemoterapia** }\end{array}$ & $\mathrm{X}$ & $\mathrm{X}$ & & & $\begin{array}{l}\text { Tratamento não descrito. Morte. } \\
\text { (extinta - renuncia direito) }\end{array}$ & - & - & $\begin{array}{l}30 / 10 / 2012 \\
14 / 06 / 2012\end{array}$ \\
\hline $\begin{array}{c}0002529- \\
64.2010 .8 .26 .0576^{37,38}\end{array}$ & $?$ & $\mathrm{~S}$ & Cirurgia Plástica & $\mathrm{X}$ & $\mathrm{X}$ & & & \begin{tabular}{|c|} 
Redução de mamas. \\
Complicações estéticas. \\
Ilegitimidade residente. \\
(CULPA)
\end{tabular} & $\mathrm{X}$ & $\mathrm{X}$ & $\begin{array}{l}26 / 03 / 2013 \\
21 / 03 / 2017\end{array}$ \\
\hline $\begin{array}{l}2007858-63.2014 .8 .26 .0000^{39} \\
0124878-71.2012 .8 .26 .0100^{40}\end{array}$ & $?$ & $\mathrm{~S}$ & $\begin{array}{l}\text { Ginecologia e } \\
\text { Obstetrícia }\end{array}$ & $\mathrm{X}$ & & $\mathrm{X}$ & & $\begin{array}{c}\text { Cisto. Cirurgia. Perfuração } \\
\text { intestinal. } \\
\text { Conduta residentes não pode ser } \\
\text { individualizada. } \\
\text { (CULPA) }\end{array}$ & $\mathrm{X}$ & $\mathrm{X}$ & $13 / 08 / 2014$ \\
\hline $\begin{array}{c}\text { 0139602- } \\
59.2007 .8 .26 .0002^{41,42,43}\end{array}$ & S & $\mathrm{S}$ & $\begin{array}{l}\text { Ginecologia e } \\
\text { Obstetrícia }\end{array}$ & $\mathrm{X}$ & & & & $\begin{array}{c}\text { Laqueadura. Reversão. } \\
\text { Gravidez. } \\
\text { (SEM CULPA) }\end{array}$ & & $\mathrm{X}$ & $\begin{array}{l}29 / 01 / 2015 \\
02 / 06 / 2015 \\
11 / 08 / 2015\end{array}$ \\
\hline $\begin{array}{l}9040853-88.2006 .8 .26 .0000^{44} \\
0070787-75.2005 .8 .26 .0100^{45-}\end{array}$ & $\mathrm{N}$ & $\mathrm{N}$ & Otorrinolaringologia & $\mathrm{X}$ & & & & $\begin{array}{c}\text { Infecção das vias aéreas } \\
\text { superiores. Tratamento. Má } \\
\text { evolução. Septicemia. Óbito. } \\
\text { (SEM CULPA) }\end{array}$ & & $\mathrm{X}$ & $\begin{array}{l}15 / 03 / 2006 \\
30 / 07 / 2009 \\
18 / 07 / 2013 \\
19 / 09 / 2013 \\
\end{array}$ \\
\hline $0016625-81.2007 .8 .26 .0320^{48}$ & ? & S & Oftalmologia & $\mathrm{X}$ & & & & $\begin{array}{l}\text { Complicações em cirurgia de } \\
\text { catarata (perda visão) } \\
\text { (SEM CULPA) }\end{array}$ & & $\mathrm{X}$ & $11 / 06 / 2015$ \\
\hline $0018226-86.2010 .8 .26 .0007^{49}$ & $\mathrm{~N}$ & $\mathrm{~N}$ & Otorrinolaringologia & $\mathrm{X}$ & & & & $\begin{array}{c}\text { Septo. Cirurgia. Fistula palatina. } \\
\text { (SEM CULPA) }\end{array}$ & & $\mathrm{X}$ & $10 / 03 / 2015$ \\
\hline $0035661-95.2011 .8 .26 .0053^{50}$ & $S$ & S & $\begin{array}{l}\text { Ginecologia e } \\
\text { Obstetrícia }\end{array}$ & $\mathrm{X}$ & & & & $\begin{array}{c}\text { Cisto. Exérese. Esquecimento de } \\
\text { gaze. Prescrição para residente. } \\
\text { (CULPA) }\end{array}$ & $x$ & $\mathrm{X}$ & $09 / 06 / 2015$ \\
\hline $\begin{array}{c}0127580- \\
29.2008 .8 .26 .0100^{51,52}\end{array}$ & $\mathrm{~S}$ & S & Gastroenterologia & $\mathrm{X}$ & & $\mathrm{x}$ & & $\begin{array}{l}\text { Erro de diagnóstico. Remoção } \\
\text { de estômago, vesícula e baço. } \\
\text { (CULPA) }\end{array}$ & $\mathrm{X}$ & & $29 / 09 / 2015$ \\
\hline $0000732-59.2009 .8 .26 .0456^{53}$ & ? & S & $\begin{array}{l}\text { Ginecologia e } \\
\text { Obstetrícia }\end{array}$ & $\mathrm{X}$ & $\mathrm{X}$ & & & $\begin{array}{l}\text { Parto. Sequela neurológica. } \\
\text { Óbito do feto. } \\
\text { (SEM CULPA) }\end{array}$ & & $\mathrm{X}$ & $02 / 03 / 2016$ \\
\hline $0127922-49.2008 .8 .26 .0000^{54}$ & $?$ & S & $\begin{array}{l}\text { Ginecologia e } \\
\text { Obstetrícia }\end{array}$ & $\mathrm{X}$ & & & & \begin{tabular}{|c|} 
Parto. Fórceps. Lesão plexo \\
branquial. \\
(IMPRUDÊNCIA, \\
NEGLIGENCIA E \\
IMPERÍCIA) \\
\end{tabular} & $\mathrm{X}$ & $\mathrm{X}$ & $11 / 03 / 2016$ \\
\hline $0014275-18.2005 .8 .26 .0506^{55}$ & $\mathrm{~S}$ & S & Cirurgia* & $\mathrm{X}$ & & & & \begin{tabular}{|c|} 
Traqueostomia. Troca de cânula. \\
Parada cardíaca. Morte. \\
(IMPRUDÊNCIA, \\
NEGLIGENCIA E \\
IMPERÍCIA) \\
\end{tabular} & $\mathrm{X}$ & & $05 / 04 / 2016$ \\
\hline $0023212-86.2003 .8 .26 .0053^{56}$ & $\mathrm{~S}$ & S & Não consta & $\mathrm{X}$ & & & & $\begin{array}{c}\text { Intracath. Perfuração do pulmão } \\
\text { (SEM CULPA) }\end{array}$ & & $\mathrm{X}$ & $15 / 04 / 2016$ \\
\hline
\end{tabular}

*sem especificação da área cirúrgica. ** especialidade do residente. ? não relatado. ? não relatado. $\mathrm{S}=\operatorname{sim}$. $\mathrm{N}$ = não. 
Quando a especialidade não era mencionada textualmente e comprovada com a busca do profissional no site do Conselho Federal de Medicina e do programa de residência oferecido pela instituição em que o fato ocorreu, ela foi referida de acordo com o procedimento sendo executado. Observa-se que Ginecologia e Obstetrícia foi a especialidade mais demandada (31\%), usualmente em situações de complexidade superior ao da aparente competência do residente, sem que comprovada a devida supervisão. Em Otorrinolaringologia, os casos trataram de intercorrências possíveis que não mereceriam indenizações, porém, em dois, estas foram consideradas devidas pela apuração da culpa do profissional. Em uma delas, o paciente perdeu a visão ${ }^{32}$ por suposta dilaceração do nervo ótico e, na outra, a hemorragia tardiamente diagnosticada levou o paciente ao óbito ${ }^{33}$. Entretanto, neste caso referente ao eventual prejuízo do nervo ótico, em sede de ação rescisória, foi apreciado que de fato o nervo ótico não havia sido dilacerado e a cegueira advinda da cirurgia resultava de complicação inerente ao complexo quadro clínico da autora ${ }^{32}$.

[...] "o procedimento médico que, ao retirar crescimento carnoso da membrana mucosa do nariz do apelante, acaba dilacerando o nervo ótico e provocando a perda da visão de uma das vistas do paciente." Ocorre que não houve dilaceramento de nervo ótico nenhum, a médica responsável pelo procedimento cirúrgico operando com o emprego de microscópio, com todo o cuidado; mas o fazia praticamente às cegas, como a petição inicial desta rescisória acentuou. [...]. Acresce notar, ainda segundo a perícia (inicial, fl. 5), que "a média da espessura da camada óssea que recobre o nervo ótico, separando-o da mucosa sinusal é de $0,54 \mathrm{~mm}$ ". Quer dizer, achar-se-ia praticamente colado a esta, rotular tal cirurgia de simples, a partir daí se constituía em rematado absurdo. Tanto que ninguém antes quis operar, em razão do risco existente, ao que se viu. [...] "Pelo laudo da Tomografia Computadorizada, realizada após a cirurgia, pode-se comprovar que o nervo óptico do autor não foi fragmentado, reconhecendo-se um barramento de imagem desta estrutura, o que caracteriza mero pinçamento do mesmo, sem qualquer corte

[...]. Não houve dilaceração do nervo ótico, fruto de atuação estabanada do cirurgião, bem ao contrário do que o acórdão colocou e a inicial sustentara no vazio. Ambas as médicas se revezavam no microscópio, como a perícia do IMESC assinalou, em nenhum momento deixaram de prestar os devidos cuidados ao paciente ${ }^{32}$.

EMENTA - INDENIZAÇÃO POR DANOS MORAIS. Demanda fundada na alegação de erro médico (ajuizada em face do hospital e dos médicos que assistiram a paciente, filha dos autores, levada a óbito durante cirurgia para retirada de adenoide) - Prova pericial indireta, inconclusiva acerca da culpa dos médicos que assistiram a paciente no ato cirúrgico - No entanto, referida conclusão se contrapõe à dos profissionais subscritores do laudo necroscópico (que efetivamente viram a paciente logo após o óbito, concluindo de forma diversa - qual seja, que a morte ocorreu por choque hipovolêmico - hemorragia) - Circunstância incomum em cirurgia de pouca complexidade e que não poderia ter passado despercebida pelos médicos - Culpa, na modalidade negligência, dos médicos que compõem o polo passivo - Caracterização - Nexo causal corretamente estabelecido ${ }^{33}$.

No Gráfico 1, pode-se observar ilustração do número de lides apuradas em $2^{\text {a }}$ instância, envolvendo residentes de medicina de acordo com a especialidade. Para uma mesma lide, apenas um acórdão foi considerado. $\mathrm{Na}$ Figura 2, tem-se o número de lides distribuídas em função do ano da decisão da apelação do caso. Como para uma mesma lide encontrou-se mais de um acórdão, optou-se por organizá-las desta maneira. Por este critério, duas lides foram excluídas, uma em que o processo foi extinto $^{35} \mathrm{e}$, portanto, não houve decisão de apelação, e outro que ainda está em julgamento ${ }^{39,40}$.

Gráfico 1. Distribuição dos casos de erro médico envolvendo médico residente no polo passivo de ações de responsabilidade civil do TJSP, de acordo com a especialidade. Período: 1/1/98 - 15/11/2016, n = 29

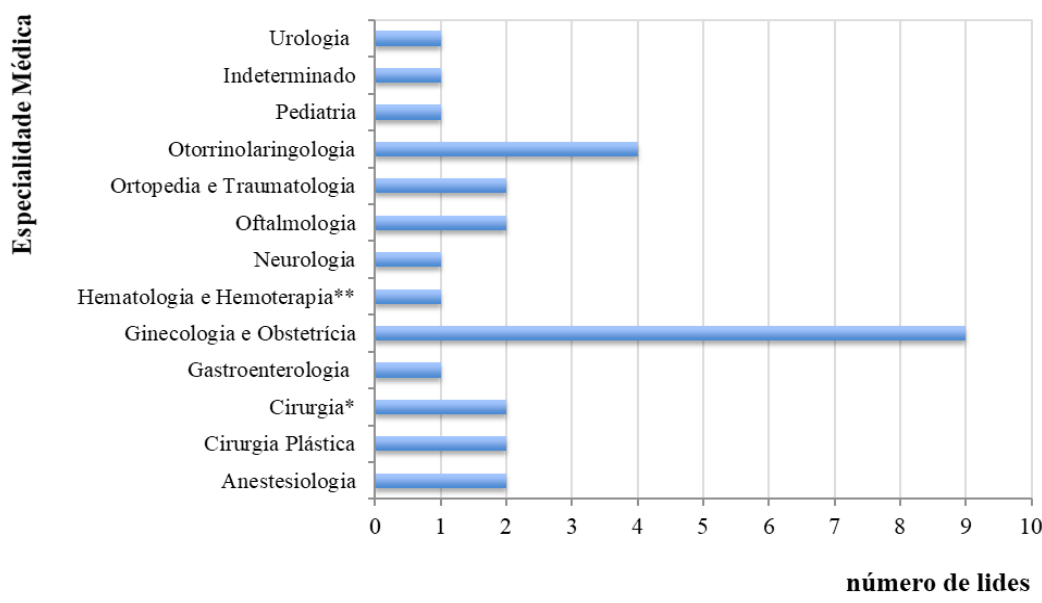

*Área cirúrgica não especificada ** Área de Especialização do residente 
Em quatorze acórdãos $(48,3 \%)$ o residente foi chamado a responder sozinho sem o responsável por sua supervisão, porém juntamente com o hospi tal $^{16,17,24,26,27,30,42,44,48-50,54-56}$. Nos demais, respondeu com outras pessoas da equipe ou do serviço: preceptor $(13,8 \%)^{19,35,37,53}$, professor do programa $(17,2 \%)^{20,32,34,35,39,51}$, médico especialista $(10,3 \%)^{17,31,33}$ e chefe do setor $(10,3 \%)^{22,23,25}$. Em apenas um caso, relacionado à especialidade de Cirurgia Plástica, o hospital não fez parte da lide ${ }^{31}$.

Nos casos em que foi chamado a responder sem a equipe, em oito $(57,1 \%)^{16,17,27,42,45,48,49,56}$ houve entendimento de que não houve culpa na conduta do residente, em quatro $(28,6 \%)^{26,30,50,54}$, por questões processuais não foi julgado, e em dois $(14,3 \%)$ sua conduta foi considerada culposa ${ }^{24,55}$. Em um caso, muito embora a residente tenha respondido sozinha pela sua conduta em um hospital, outros médicos compuseram a lide, médicos que atenderam o paciente em outras instituições ${ }^{45}$.

Das quatro lides em que respondeu com o preceptor, uma foi extinta por desistência do autor ${ }^{35}$, e nas demais entendeu-se que a culpa seria do responsável pelo treinamento. Das que respondeu com o professor, em apenas um caso, considerado de erro grosseiro, foi responsabilizado junto ao mesmo. Tratou-se de erro de diagnóstico de laboratório em que o residente e o professor removeram baço, vesícula e estômago de paciente, pelo laudo errôneo de malignidade ${ }^{51}$ :

Ação de reparação de danos materiais e morais. Responsabilidade civil atendimento no sistema público de saúde. Erro de diagnóstico. Paciente que se queixava de fortes dores estomacais decorrentes de gastrite avançada até então desconhecida. Exame laboratorial que concluiu, erroneamente, pelo diagnóstico de câncer de estômago com metástase para o baço e vesícula biliar. Médicos públicos que optaram por extrair três órgãos do autor (estômago, baço e vesícula) sem qualquer exame complementar ou maior diligência. Posterior biópsia realizada nos órgãos concluiu pela ausência de câncer, mas mera gastrite. Situação surreal que merece reparação, pois nitidamente implicou consequências graves e funestas para a vida do autor. [...] Diante disso, era mesmo cabida a condenação dos réus de forma solidária ao pagamento dos danos morais sofridos, tal como fixado na sentença atacada. Grifa-se.

Entretanto, neste caso, em voto vencido, percebese o entendimento contrário baseado no laudo pericial ${ }^{52}$ :

Portanto, tem-se que a conduta dos médicos se coaduna à descrição da literatura médica apresentada pelo jurisperito para o diagnóstico de câncer de estômago, pois a junção do exame clínico e do laboratorial apontava para referida patologia. Nesse ponto, vale frisar o seguinte trecho do laudo pericial (fls. 836): "Este achado macroscópico, somado aos dados clínicos do indivíduo, é sugestivo de neoplasia maligna, sendo que o resultado da biópsia endoscópica revelando câncer, assim, é indicativo de estadiamento e de intervenção cirúrgica, como foi realizado. Geralmente, não é recomendada a repetição do exame endoscópico e nova biópsia para confirmação, em casos semelhantes, pelo acima relatado. [...] O corréu [...] e seu orientando [...] (médico residente), baseados no resultado do exame apresentado pelo laboratório corréu foram induzidos a erro médico, que acabou por submeter o apelado a procedimento inadequado para o tipo de patologia de que, verdadeiramente, padecia. Portanto, não se trata de erro grosseiro, mas escusável, pois amparado por diagnóstico errôneo. Por fim, no que toca à responsabilidade dos médicos, de se destacar que o corréu [...] era médico residente do laboratório de cirurgia do aparelho digestivo à época dos fatos, de modo que orientado pelo corréu [...], e não poderia, diante dos fatos em questão, ser considerado culpado pelo procedimento cirúrgico adotado por seu orientador, fosse o caso de responsabilizá-lo. Grifa-se.

Quando da avaliação da conduta junto a outros profissionais do serviço $(20,7 \%)$, como especialistas ou chefes do setor em que as decisões não descrevem hierarquia acadêmica entre os profissionais, os residentes foram condenados em todas, sempre com averiguação da culpa (negligência, imperícia e imprudência).

No entendimento do Tribunal, em dez pleitos $(34,5 \%)$ houve conduta antijurídica do residente, com consequente dano ao paciente. Os tipos de danos que motivaram as lides foram distintos em sua maioria. Desfecho com morte ocorreu em 6 casos $(17,2 \%)^{22,33,35,45,53,55}$

Das 28 lides em que o hospital foi mencionado ou participou do polo passivo, em dez estes eram públicos e, em 14, os sites institucionais descrevem que estes realizam atendimento pelo Sistema Único de Saúde, SUS, variando de $4 \%$ a $100 \%$ do seu fluxo de atendimento.

\section{DISCUSSÃO}

O dano ressarcível é definido como aquele resultante de ato ilícito, imprescindível para a configuração da responsabilidade civil, conforme estabelecido no art. 927 do Código Civil brasileiro5. A doutrina brasileira entende que o dano reflete a diminuição do patrimônio, tanto material como moral e estético ${ }^{4}$. 
Gráfico 2. Distribuição dos casos de erro médico envolvendo médico residente no polo passivo de ações de responsabilidade civil do TJSP, de acordo com o ano do julgamento da apelação.

$$
\text { Período: } 1 / 1 / 98-15 / 11 / 2016, \mathrm{n}=27
$$

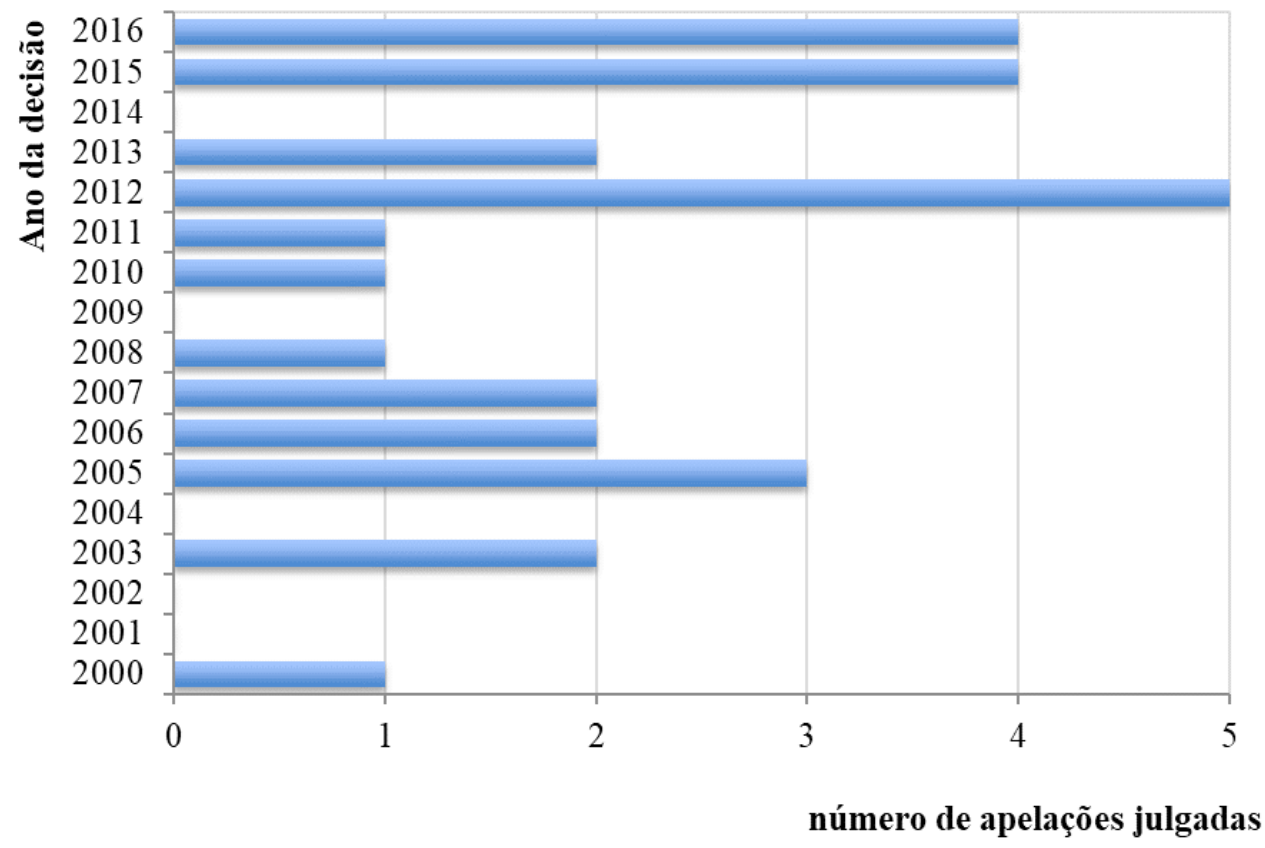

Dados: TJSP, 2016

Quando a relação estabelecida entre as partes, médico e paciente, for contratual, as lides são dirimidas pelo Código do Consumidor ${ }^{6}$, pois entende-se que houve defeito na prestação de serviço:

Art. 14. O fornecedor de serviços responde, independentemente da existência de culpa, pela reparação dos danos causados aos consumidores por defeitos relativos à prestação dos serviços, bem como por informações insuficientes ou inadequadas sobre sua fruição e riscos.

$\S 1^{\circ} \mathrm{O}$ serviço é defeituoso quando não fornece a segurança que o consumidor dele pode esperar, levandose em consideração as circunstâncias relevantes, entre as quais:

I - o modo de seu fornecimento;

II - o resultado e os riscos que razoavelmente dele se esperam;

III - a época em que foi fornecido.

$\S 2^{\circ} \mathrm{O}$ serviço não é considerado defeituoso pela adoção de novas técnicas.

$\S 3^{\circ} \mathrm{O}$ fornecedor de serviços só não será responsabilizado quando provar:

I - que, tendo prestado o serviço, o defeito inexiste; II - a culpa exclusiva do consumidor ou de terceiro. $\S 4^{\circ}$ A responsabilidade pessoal dos profissionais liberais será apurada mediante a verificação de culpa. Grifa-se.

Nestes casos, para que seja procedente o dever de indenizar, há que se comprovar a existência do dano, da conduta antijurídica comissiva ou omissiva do agente, o nexo causal (liame entre a ação do agente e o dano), e a culpa do profissional liberal (responsabilidade subjetiva), culpa esta decorrente de negligência, imperícia ou imprudência. É importante destacar que a intercorrência médica, nestes casos, não se enquadra como defeito na prestação do serviço, pois entende-se que dentro de uma conduta correta, desvios são esperados pela própria resposta biológica do indivíduo e estatísticas relacionadas às técnicas inerentes a cada caso. Por não ser defeito de prestação de serviço, afasta-se a responsabilidade civil do prestador, desde que o paciente tenha sido exposto a riscos e resultados que razoavelmente poderiam ser esperados $1,4,57,58$.

Também afastam o dever de indenizar a culpa do próprio consumidor e a de terceiros. Todavia, o texto da lei é claro com relação à necessidade de informar o paciente com relação aos riscos da conduta a que irá se submeter, informação esta nunca presumida, sempre comprovada.

Por outrolado, quando a relação for extracontratual, ou seja, quando não há vínculo contratual entre o profissional e o paciente como nos casos de atendimento em hospitais públicos ou em hospitais privados prestadores de serviço público, a responsabilidade civil não se pauta pelo Código do Consumidor ${ }^{6}$, mas pela Constituição Federal ${ }^{15}$, art. $37 \S 6^{\circ}$, e Código Civil ${ }^{5}$, em seu art. 43:

Art. 37. A administração pública direta e indireta de qualquer dos Poderes da União, dos Estados, do Distrito 
Federal e dos Municípios obedecerá aos princípios de legalidade, impessoalidade, moralidade, publicidade e eficiência e, também, ao seguinte:

$\S 6^{\circ}$ As pessoas jurídicas de direito público e as de direito privado prestadoras de serviços públicos responderão pelos danos que seus agentes, nessa qualidade, causarem a terceiros, assegurado o direito de regresso contra o responsável nos casos de dolo ou culpa. ${ }^{15}$

Art. 43. As pessoas jurídicas de direito público interno são civilmente responsáveis por atos dos seus agentes que nessa qualidade causem danos a terceiros, ressalvado direito regressivo contra os causadores do dano, se houver, por parte destes, culpa ou dolo. ${ }^{5}$

Nestes casos, a responsabilidade do Estado é objetiva, ou seja, será averiguada por meio da caracterização da existência do dano e do nexo que este guarda com conduta omissa ou comissiva do ente estatal ou privado no exercício de serviço público. É certo que nos casos de erro médico, a averiguação da conduta danosa e o afastamento do dano como intercorrência acabam por vezes pela apreciação da culpa do profissional. Portanto, a regra em ações de responsabilidade objetiva de hospitais públicos é que, no dever de indenizar, não se avalie a culpa do agente público na conduta que ensejou o dano, muito embora seja possível que, em determinados litígios, ela acabe por ser apreciada, principalmente quando não for suscitada a ilegitimidade do agente na lide.

Em decisão de 2016, esta matéria foi apreciada ${ }^{59}$ :

O Tribunal de origem, por sua vez, manteve a condenação da parte recorrente sob a lacônica afirmação de que "não há dúvida de que a autora experimentou o resultado lesivo, que este ocorreu em virtude da intervenção médica, realizada pela profissional acionada, integrante do hospital público da Municipalidade, quando do parto, que não se corrigiu a lesão quando voltou ao tratamento, foi internada e recebeu sonda e prescrição de uso de fralda cirúrgica por longo tempo e que veio a curar-se devido a outra intervenção cirúrgica, realizada por outro médico em outro hospital" (fl. 107).

Como se vê, as instâncias de origem apenas assentaram a presença do ato da agente pública, do dano e do nexo causal entre eles, requisitos que, embora suficientes para ensejar a condenação do Município de Santos à obrigação de indenizar, não são hábeis a imputar tal obrigação também à recorrente. Com efeito, para que fosse condenada, era imprescindível uma demonstração clara de que agiu com negligência, imprudência ou imperícia, o que não aconteceu. Grifa-se.

Em dez das 29 lides analisadas, o médico com certeza atuou como agente público e, deste modo, não deveria ter composto o polo passivo da ação uma vez que o entendimento constitucional vigente é de que o Estado é quem responde pelo serviço por ele prestado, segundo o princípio da dupla garantia. Isto porque "a obrigação de indenizar é da pessoa jurídica a que pertencer o agente". De acordo com o princípio da impessoalidade, o prejudicado há que mover a ação de indenização contra "a fazenda pública respectiva ou contra a pessoa jurídica privada prestadora de serviço público, não contra o agente causador do dano" $" 60$ :

\section{RESPONSABILIDADE OBJETIVADOESTADO: $\S 6^{\circ}$ DO ART. 37 DA MAGNA CARTA. ILEGITIMIDADE PASSIVA AD CAUSAM. AGENTE PÚBLICO (EX- PREFEITO). PRÁTICA DE ATO PRÓPRIO DA FUNÇÃO. DECRETO DE INTERVENÇÃO. O $\S 6^{\circ}$ do artigo 37 da Magna Carta autoriza a proposição de que somente as pessoas jurídicas de direito público, ou as pessoas jurídicas de direito privado que prestem serviços públicos, é que poderão responder, objetivamente, pela reparação de danos a terceiros. Isto por ato ou omissão dos respectivos agentes, agindo estes na qualidade de agentes públicos, e não como pessoas comuns. Esse mesmo dispositivo constitucional consagra, ainda, dupla garantia: uma, em favor do particular, possibilitando-lhe ação indenizatória contra a pessoa jurídica de direito público, ou de direito privado que preste serviço público, dado que bem maior, praticamente certa, a possibilidade de pagamento do dano objetivamente sofrido. Outra garantia, no entanto, em prol do servidor estatal, que somente responde administrativa e civilmente perante a pessoa jurídica a cujo quadro funcional se vincular. Recurso extraordinário a que se nega provimento. ${ }^{61}$}

Mais recentemente, houve confirmação deste entendimento dos Tribunais Superiores que, como visto no presente estudo, não está pacificado nos inferiores ${ }^{62}$ :

Agravo regimental no recurso extraordinário com agravo. Administrativo. Responsabilidade civil do estado. Inclusão do agente público no polo passivo da demanda. Impossibilidade. Ilegitimidade passiva. Precedentes.

1. A jurisprudência da Corte firmou-se no sentido de não reconhecer a legitimidade passiva do agente público em ações de responsabilidade civil fundadas no art. $37, \S 6^{\circ}$, da Constituição Federal, devendo o ente público demandado, em ação de regresso, ressarcir-se perante o servidor quando esse houver atuado com dolo ou culpa. 2. Agravo regimental não provido. Grifa-se.

Sendo assim, residentes e médicos demandados junto com o hospital público ou com a fazenda pública, na qualidade de agentes públicos não poderiam ter feito parte da lide ou terem sido denunciados para dela participarem por serem parte ilegítima do pleito. Nas outras catorze ações em que o residente atuou para entidade privada que presta serviços públicos, se configurada sua conduta como agente público (atendimento pelo SUS) no caso em 
questão, nestas também não deveria ter participado no polo ativo da lide. Assim foi o entendimento encontrado em acórdão que foi excluído da amostra exatamente pela não participação do residente no polo passivo ${ }^{63}$ :

\begin{abstract}
Ainda que o autor tenha sido atendido pela Associação Prudentina de Educação e Cultura APEC, entidade privada, o atendimento se deu na condição de prestadora de serviço público no âmbito do Sistema Único de Saúde SUS e por isso sob a responsabilidade concorrente do Estado de São Paulo. Grifa-se.
\end{abstract}

Em outro caso, o juízo inicialmente aceitou a denunciação à lide dos residentes, isto é, foram chamados para compor o polo passivo da ação depois de proposta a inicial pelo paciente autor. Contudo, em sua decisão sobre o caso, o juiz os excluiu considerando que seriam partes ilegítimas do feito ${ }^{54}$ :

\begin{abstract}
No que toca à lide secundária, de se ver que muito embora tenha sido admitida denunciação à lide dos médicos [...] e [...], após detida análise do caso observo que realmente não estão presentes os requisitos que justificariam a adoção de tal medida. Como se sabe, a denunciação da lide está associada ao requisito da conexão com a ação principal e ao exercício do direito de regresso, de tal sorte que ao se analisar aquela lide e decidir-se pela condenação do réu, obtenham-se elementos aptos a justificar também a condenação do denunciado em reparar os prejuízos que aquele venha a sofrer em decorrência da ação, ou seja, de reaver, daquele por quem pagou, o que houver pago. No caso, diante da relação jurídica que vincula o hospital réu e os médicos denunciados, tornar-se-ia necessário, para configurar o necessário direito de regresso, perquirir-se e provar que eles desrespeitaram as regras e procedimentos que regem o vínculo empregatício e, especialmente, se agiram com imprudência, negligência ou imperícia, considerando as condições de trabalho que dispunham para o atendimento da paciente, do que não se pode cogitar no presente caso, em vista da impossibilidade de se inserir fundamento estranho à lide principal.
\end{abstract}

A denunciação à lide de agentes públicos (ou sua vedação) não é matéria pacífica na doutrina do direito ou na jurisprudência do STJ, principalmente com o novo texto do Código de Processo Civil ${ }^{64}$, que assegura o instituto para aqueles cujo Estado tem direito de promover ação de regresso (de quem o Estado pode cobrar, caso seja condenado). Em Resp. da Ministra Eliana Calmon ${ }^{65}$, anterior à vigência do novo código, esta discorre atentamente sobre a matéria e posicionase contra seu cabimento. Posteriormente, não se encontraram decisões no STJ sobre a matéria tendo como base o novo Código de Processo Civil. Em São Paulo, apenas uma decisão do TJSP aborda diretamente o tema da possibilidade da denunciação à lide de agente público em lide com o Estado, e, no caso, entendeu o relator que esta não caberia porque, a rigor, a "responsabilidade civil do Estado é objetiva, de modo que o exame da pretensão indenizatória deduzida pelas vítimas independe da prova de culpa ou dolo na conduta do agente supostamente causador do dano" $"$.

Nas ações regidas pelas obrigações contratuais e, portanto, dirimidas pelo Código do Consumidor ${ }^{6}$, a denunciação à lide de pessoas que não foram chamadas ao pleito na petição inicial, embora instituto vedado genericamente pelo código consumerista, era aceito nos casos de defeito na prestação de serviço. Todavia o entendimento dos Tribunais mudou neste sentido, e hoje não mais se aceita este tipo de composição ${ }^{67}$ :

\section{RECURSO ESPECIAL. RESPONSABILIDADE CIVIL. INDENIZAÇAO POR DANOS MORAIS. DEFEITO NAPRESTAÇAODOSERVIÇOACONSUMIDOR. DENUNCIAÇAO DA LIDE. INTERPRETAÇAO DO ART. 88 DO CDC. IMPOSSIBILIDADE. 1. A vedação à denunciação da lide prevista no art. 88 do $\mathrm{CDC}$ não se restringe à responsabilidade de comerciante por fato do produto (art. 13 do CDC), sendo aplicável também nas demais hipóteses de responsabilidade civil por acidentes de consumo (arts. 12 e 14 do CDC) [...].}

E quando se poderia alegar a ilegitimidade dos agentes públicos no polo passivo, ou a denunciação à lide do residente em qualquer situação (como agente público ou não), em ações regidas pelo $\mathrm{CDC}^{6}$ ou pelo Código Civil ${ }^{5}$ ? A qualquer momento até o trânsito em julgado da decisão, já que é matéria de direito público ${ }^{64}$.

Deste modo, não é possível, ao residente demandado, requisitar que o seu preceptor seja denunciado à lide para que responda pela sua participação na conduta lesiva, usualmente por conduta omissiva deste. Pode, contudo, demandar que sua conduta seja avaliada apenas frente às capacitações já conquistadas, conforme entendimento do STJ $^{68}$ :

RESPONSABILIDADE CIVIL. Médico. Médicoresidente. Acórdão. Falta de fundamentação. Embargos de declaração.

- Suficiente fundamentação do acórdão que estabeleceu a relação causal entre a atividade dos réus e o resultado morte da paciente.

- Responsabilização do médico-residente pelos atos que estava habilitado a praticar em razão de sua graduação. Diferença do grau de responsabilidade entre a dos residentes e a do médico orientador, que não se leva em conta porque já fixada a condenação no mínimo.

- Embargos de declaração rejeitados, com aplicação de multa. Recurso especial não conhecido. Grifa-se.

Nesta amostra jurisprudencial, quando o residente foi demandado junto à equipe do programa de residência, o entendimento foi de que seus superiores 
hierárquicos respondessem pela indenização, visto que os primeiros careciam de autonomia ou conhecimento para a tomada de decisões, o que trouxe grande carga de responsabilidade à preceptoria e ao corpo docente em casos de responsabilidade civil. Com isso, é importante que se discuta, no contexto destes programas, a responsabilidade dos profissionais da equipe acadêmica, e que a supervisão de fato se realize e se materialize em procedimentos e condutas rastreáveis.

Nos casos estudados, apesar de por força de lei a conduta do médico residente ter que ser supervisionada por médico responsável, os residentes responderam a lide isoladamente em quase metade da jurisprudência (48,27\%). Nestes, não houve discussão sobre sua falta de autonomia frente aos médicos do serviço em que se inseriam, não ficando clara a relação de capacitação à qual estavam submetidos. De fato, se tomam decisão de conduta por si e não se submetem à supervisão são legalmente responsáveis pelo ato médico que conduzem, dentro da habilitação já alcançada, entendimento corroborado pelo CFM $^{11}$.

Em especial, é necessário que se discuta, nas residências, o maior risco de ocorrência de intercorrências percebidas como erro médico em condutas cirúrgicas. A análise da jurisprudência estudada permitiu observar que em todos os casos houve algum procedimento invasivo realizado pelo profissional, que culminou em um resultado insatisfatório, mesmo que a conduta não tenha sido considerada culposa. Este resultado, apesar da pequena amostra, acompanha outros estudos nacionais e internacionais que apontam áreas cirúrgicas, principalmente em ginecologia e obstetrícia, como as mais demandadas frente à má-prática profissional ${ }^{8,69}$. É importante para o residente e para o hospital ter clara a relação deste com os demais membros da equipe hospitalar e sua hierarquia na tomada de decisões. A residência não deve permitir o exercício não supervisionado dos profissionais em treinamento.

Ainformaçãopréviaeadequadafoiimportantíssima como prova da correção profissional. Na amostra, o dever de informação foi com frequência citado. Nos casos em que houve reversão da laqueadura ${ }^{41-43}$ e da vasectomia ${ }^{16}$, por exemplo, a comprovação por meio do consentimento assinado foi fundamental para confirmar a orientação com relação à contracepção e falibilidade do método, sendo que naquela primeira ação, a oitiva de testemunhas comprovou a capacidade da compreensão da autora ${ }^{42}$ :

RESPONSABILIDADE CIVIL - Ação reparatória proposta em face do hospital e da médica fundada em falha no dever de informar Alegação de falta de comunicação à autora de que o método não era totalmente seguro. Conjunto probatório que não demonstrou essas assertivas. Superveniência de gravidez indesejada Procedimento cirúrgico realizado corretamente $[\ldots]$
Laudo pericial nesse sentido Existência de documento assinado pela requerente e seu marido, contendo as limitações do método. Esterilização não garantida. Dever de informação cumprido quanto à falibilidade do método contraceptivo. Ausência de ato ilícito que justifique a obrigação de indenizar - Recurso provido.

Já em um dos casos de cirurgia plástica, a falta de informação contribuiu para a condenação ${ }^{37}$ :

[...] Sendo assim, competia aos réus comprovar que empregaram todos os esforços na busca do resultado prometido ou adequado, para afastar a presunção de culpa, ou demonstrar que resultado melhor só não foi alcançado, por força de intercorrência previsível, previamente informada à autora, mormente eventuais resultados desfavoráveis do processo de cicatrização, fato que, não se tem notícia nos autos.

O dever de informação, amparado pelo Código de Ética Médica ${ }^{70}$, no direito médico edifica-se como verdadeiro princípio, que se fundamenta na dignidade da pessoa humana ${ }^{15}$, na liberdade de ação e na livre escolha determinada pelo Código Civil (art. 15) ${ }^{5}$, conceitos agasalhados constitucionalmente ${ }^{15}$. Mais especificamente, o Código do Consumidor ${ }^{6}$ determina que é dever do prestador de serviços fornecer informações suficientes e adequadas sobre serviço (médico) a ser prestado e, no Estado de São Paulo, tem-se ainda a Lei n ${ }^{\circ} 10.241$, de $1999^{71}$ :

Artigo $2^{\circ}$ - São direitos dos usuários dos serviços de saúde no Estado de São Paulo: [...]

VI - receber informações claras, objetivas e compreensíveis sobre:

a) hipóteses diagnósticas;

b) diagnósticos realizados;

c) exames solicitados;

d) ações terapêuticas;

e) riscos, benefícios e inconvenientes das medidas diagnósticas e terapêuticas propostas;

f) duração prevista do tratamento proposto;

g) no caso de procedimentos de diagnósticos e terapêuticos invasivos, a necessidade ou não de anestesia, o tipo de anestesia a ser aplicada, o instrumental a ser utilizado, as partes do corpo afetadas, os efeitos colaterais, os riscos e consequências indesejáveis e a duração esperada do procedimento;

h) exames e condutas a que será submetido;

i) a finalidade dos materiais coletados para exame;

j) alternativas de diagnósticos e terapêuticas existentes, no serviço de atendimento ou em outros serviços; e

1) o que julgar necessário;

VII - consentir ou recusar, de forma livre, voluntária e esclarecida, com adequada informação, procedimentos diagnósticos ou terapêuticos a serem nele realizados;

VIII - acessar, a qualquer momento, o seu prontuário 
médico, nos termos do artigo $3^{\circ}$ da Lei Complementar n. 791, de 9 de março de 1995;

IX - receber por escrito o diagnóstico e o tratamento indicado, com a identificação do nome do profissional e o seu número de registro no órgão de regulamentação e controle da profissão;[...]. Grifase.

Quanto aos valores da lide, sabe-se que acompanham a extensão do dano e que variam enormemente de acordo com a natureza da lesão praticada e com as características da vítima. Comparando-se uma mesma cicatriz de um senhor idoso e em uma modelo, entende-se que o dano a ser ressarcido será distinto para cada caso já que comparações diretas do sofrimento são impossíveis. Deste modo, optou-se por não apresentar os valores das condenações neste trabalho. Apenas a título informativo, em uma das ações o pedido inicial trouxe o dano em ricochete, que culminou com o maior valor concedido. Neste instituto jurídico, permite-se avaliar o sofrimento que recai sobre os familiares daquele que sofreu o dano (cônjuges ou companheiros, filhos, pais e irmãos), por analogia à inteligência do parágrafo único do art. 12, art. 20 e art. 948, II do Código Civil ${ }^{4,5}$. Este entendimento alcança o STJ como indicou a ministra Nancy Andrighi em sua decisão no REsp 1.208.949: "Reconhece-se a legitimidade ativa dos pais de vítima direta para, conjuntamente com essa, pleitear a compensação por dano moral por ricochete, porquanto experimentaram, comprovadamente, os efeitos lesivos de forma indireta ou reflexa"72.

\section{CONCLUSÃo}

A jurisprudência do Tribunal paulista sobre erro médico de residentes indica que estes são julgados como profissionais que são, mediante a apreciação da culpa lato sensu (negligência, imperícia e imprudência) nos casos de responsabilidade civil por erro médico. Todavia, quando foram julgados juntamente com seus pares acadêmicos, professores ou preceptores, a culpa, se presente, foi dirimida em favor daqueles já que careciam de autonomia na conduta. Quando da presença de suposto erro grosseiro, entendeu-se que seriam culpados juntamente com os profissionais aos quais se submetiam, em consonância com decisão do STJ em que devem ser responsabilizados pelos atos habilitados em razão da graduação ${ }^{68}$.

Mesmo em situações em que por força de lei a regra deveria ser o atendimento prestado pelo residente sob supervisão docente, este respondeu a ação isoladamente em praticamente metade da amostra. Como o Código do Consumidor veda que a equipe docente seja chamada ao processo se esta não foi demandada pelo autor da ação, os pedidos para que os demais médicos fossem incluídos foram negados. Nos casos em que o residente respondeu com a equipe de médicos do hospital, sem que fosse citada hierarquia acadêmica entre os profissionais, houve condenação em todos, sempre pela constatação da conduta antijurídica e culpa.

Nos casos em que atuou como agente público em serviços públicos, estes não deveriam ter participado da lide por garantia Constitucional ${ }^{15}$. Contudo, a ilegitimidade processual não foi suscitada tempestivamente e os residentes acabaram por participar dos pleitos. O mesmo ocorreu para aqueles que, em entidades privadas, prestaram serviço público. Em geral, esta jurisprudência enfatizou a importância da informação na relação médico paciente, principalmente para afastar a responsabilidade quando da ocorrência de intercorrências.

Kurauchi ATN, Piacsek MVM, Motta MV. Civil Responsibility of the Medical Resident: Jurisprudence in the State of São Paulo. Saúde, Ética \& Justiça. 2017;22(1):26-40.

\begin{abstract}
During residency, physicians can be sued for medical errors under civil or consumer legislation, as a public or private service provider, respectively. This research evaluated the jurisprudence of the regional Court of the state of São Paulo in which medical residents figured as defendants in medical malpractice lawsuits, from January 1998 to December 2016. The Court decisions indicated that when residents were accompanied by their academic hierarchic superiors in the litigation, the claim evaluated only the conduct of the later, except in gross negligence cases. When they were sued with other physicians of the hospital staff with whom they did not share academic relation, their conduct in relation to the alleged damages was individually evaluated for negligence, violation of the standard of care, and recklessness. In the litigations in which they were the only defendants along with the hospital, they lost the case in only two occasions (14.3\%). Although many of the private institutions of this jurisprudence also provided public services, both their physicians and residents should not have participated in the litigations, as it is legally forbidden for public agents to do so, but their legitimacy as defendants was not timely contested. The medical duty to provide information to the patients was emphasized in many decisions, in order to explain conducts and possible adverse effects. Lacking of documentation of such procedures per se may bring the understanding to the magistrate that punitive damages are due.
\end{abstract}

KEY WORDS: Internship and Residency/LJ; Medical Errors; Consumer Advocacy; Administrative Law; Malpractice; Jurisprudence; Liability, Legal; Damage Liability. 


\section{REFERÊNCIAS}

1. Gomes JCM, Franca GV. Erro médico. In: Costa SIF, Oselka G, Garrafa V. Iniciação à bioética. Brasília: Conselho Federal de Medicina; 1998. p.243-56.

2. Gomes P. Erro médico provoca sequelas e disparada de processos na Justiça. Folha de São Paulo [Internet]. 2016 [acesso em 2017 jan. 7]. Disponível em: http://www1. folha.uol.com.br/cotidiano/2016/08/1802579-erro-medicoprovoca-sequelas-e-disparada-de-processos-na-justica. shtml

3. Rio de Janeiro. Tribunal de Justiça do Estado do Rio de Janeiro. 12 ${ }^{\text {a }}$ Câmara Cível. Apelação. Processo n ${ }^{\circ} 0106857$ 58.2006.8.19.0001. Relator: Lúcia Maria Miguel da Silva Lima. Julgado em: 5 fev. 2009.

4. Cavalieri Filho S. Programa de Responsabilidade Civil. 10 ed. São Paulo: Atlas; 2012. p. 98-9.

5. Brasil. Presidência da República, Casa Civil, Subchefia para Assuntos Jurídicos. Lei no 10.406 , de 10 de janeiro de 2002. Institui o Código Civil [Internet]. Brasília, DF; 2002 [acesso em 2017 jan. 7]. Disponível em: www.planalto.gov. br/ccivil_03/leis/2002/L10406compilada.htm

6. Brasil. Presidência da República, Casa Civil, Subchefia para Assuntos Jurídicos. Lei no 8.078 , de 11 de setembro de 1990. Dispõe sobre a proteção do consumidor e dá outras providências [Internet]. Brasília, DF; 1990 [acesso em 2017 jan. 7]. Disponível em: http://www.planalto.gov.br/ ccivil 03/leis/L8078.htm

7. Brasil. Superior Tribunal de Justiça. Recurso Especial $\mathrm{n}^{\circ}$ 1.180.815. Relatora: Ministra Nancy Andrighi. $3^{\mathrm{a}}$ Turma. Julgado em: 26 ago. 2010

8. Bitencourt AGV, Neves NMBC, Neves FBCS, Brasil ISPS, Santos LSC. Análise do erro médico em processos éticoprofissionais: implicações na educação médica. Rev Bras Educ Med. 2007;31(3):223-8.

9. Brasil. Presidência da República, Casa Civil, Subchefia para Assuntos Jurídicos. Lei $\mathrm{n}^{\circ}$ 6.932, de 7 de julho de 1981. Dispõe sobre as atividades do médico residente e dá outras providências [Internet]. Brasília, DF; 1981 [acesso em 2017 jan. 7]. Disponível em: www.planalto.gov.br/ ccivil 03/Leis/L6932.htm

10. Brasil. Conselho Nacional de Residência Médica (CNRM). Resolução $\mathrm{n}^{\circ}$ 4, de 9 de novembro de 1978. Estabelece normas gerais, requisitos mínimos e sistemática de credenciamento da Residência Médica [Internet]. Brasília, DF; 1978 [acesso em 2017 jan. 7]. Disponível em: http:// portal.mec.gov.br/sesu/arquivos/pdf/CNRM0478.pdf

11. Brasil. Conselho Federal de Medicina (CFM). Parecer $n^{0}$ 3/1992. Relator: Hilário Lourenço de Freitas Junior [Internet]. Aprovado em: 16 jan. 1992 [acesso em 2017 jul. 5]. Disponível em: www.portalmedico.org.br/pareceres/ CFM/1992/3 1992.htm

12. São Paulo. Tribunal de Justiça do Estado de São Paulo. E-SAJ portal de Serviços. Consulta completa [Internet]. São Paulo; 2017 [acesso em 2017 jan. 7]. Disponível em: https://esaj.tjsp.jus.br/cjsg/consultaCompleta.do

13. São Paulo. Tribunal de Justiça do Estado de São Paulo. E-SAJ portal de Serviços. Consulta de processos de $1^{\circ}$ grau [Internet]. São Paulo; 2017 [acesso em 2017 jan. 7]. Disponível em: https://esaj.tjsp.jus.br/cpopg/open.do
14. Brasil. Conselho Federal de Medicina. Busca de Médicos [Internet]. Brasília, DF; 2017 [acesso em 2017 jan. 7]. Disponível em: http://portal.cfm.org.br/index. php?option=com_medicos\&Itemid $=59$

15. Brasil. Presidência da República, Casa Civil, Subchefia para Assuntos Jurídicos. Constituição da República Federativa do Brasil de 1988 [Internet]. Brasília, DF; 1988 [acesso em 2017 jul. 5]. Disponível em: www.planalto.gov.br/ ccivil 03/constituicao/constituicao.htm

16. São Paulo. Tribunal de Justiça do Estado de São Paulo. Apelação. Processo $\mathrm{n}^{\mathrm{o}}$ 9038651-22.1998.8.26.0000. $2^{\mathrm{a}}$ Câmara de Direito Público. São Paulo. Relator: Correa Vianna. Julgado em: 24 out. 2000.

17. São Paulo. Tribunal de Justiça do Estado de São Paulo. Apelação. Processo $\mathrm{n}^{\circ}$ 9092473-86.1999.8.26.0000. Campinas. Relator: Munhoz Soares. Julgado em: 29 mai. 2003.

18. São Paulo. Tribunal de Justiça do Estado de São Paulo. Apelação. Processo $\mathrm{n}^{\circ}$ 9171717-30.2000.8.26.0000. Campinas. Relator: Caetano Lagrasta. Julgado em: 19 mai. 2005.

19. São Paulo. Tribunal de Justiça do Estado de São Paulo. Apelação Processo $\mathrm{n}^{\circ}$ 9196967-65.2000.8.26.0000. Ribeirão Preto. Relator: J. Roberto Bendran. Julgado em: 25 fev. 2003.

20. São Paulo. Tribunal de Justiça do Estado de São Paulo. Embargos Infringentes. Processo $\mathrm{n}^{0}$ 916691433.2002.8.26.0000. Sumaré. Relator: Maury Angelo Bottesini. Julgado em: 28 abr. 2006.

21. São Paulo. Tribunal de Justiça do Estado de São Paulo. Apelação cível com Revisão. Processo $n^{0}$ 916691433.2002.8.26.0000. Sumaré. Relator: Ana Luiza Liarte. Julgado em: 23 jun. 2008.

22. São Paulo. Tribunal de Justiça do Estado de São Paulo. Apelação cível com Revisão. Processo $n^{\circ}$ 910488629.2002.8.26.0000. Araçatuba. Relator: Ribeiro da Silva. Julgado em: 30 nov. 2006.

23. São Paulo. Tribunal de Justiça do Estado de São Paulo. Apelação cível com Revisão. Processo $n^{\circ}$ 921979232.2002.8.26.0000. Valinhos/Campinas. Relator: José Roberto Bedran. Julgado em: 19 jun. 2007.

24. São Paulo. Tribunal de Justiça do Estado de São Paulo. Apelação cível com Revisão. Processo $n^{\circ} 9156055-$ 84.2004.8.26.0000. Campinas. Relator: Ivan Sartori. Julgado em: 16 jul. 2007.

25. São Paulo. Tribunal de Justiça do Estado de São Paulo. Apelação. Processo $\mathrm{n}^{\mathrm{o}}$ 9193021-17.2002.8.26.0000. Catanduva. Relator: Teixeira Leite. Julgado em: 17 jan. 2008.

26. São Paulo. Tribunal de Justiça do Estado de São Paulo. Apelação. Processo $\mathrm{n}^{\mathrm{o}}$ 9196454-29.2002.8.26.0000. $8^{\mathrm{a}}$ Câmara de Direito Privado. Cotia. Relator: Luiz Ambra. Julgado em: $1^{\circ}$ dez. 2010

27. São Paulo. Tribunal de Justiça do Estado de São Paulo. Apelação. Processo $n^{0}$ 0201825-74.2009.8.26.0100. São Paulo. Relator: Sebastião Carlos Garcia. Julgado em: 26 mai. 2011.

28. São Paulo. Tribunal de Justiça do Estado de São Paulo. Apelação. Processo $\mathrm{n}^{0}$ 0201822-22.2009.9.26.0100. São Paulo. Relator: Sebastião Carlos Garcia. Julgado em: 15 
set. 2011.

29. São Paulo. Juízo da $6^{\mathrm{a}}$ Vara de Ribeirão Preto. Ação de Responsabilidade Civil por Erro Médico. Processo $\mathrm{n}^{\mathrm{o}}$ 0050924-50.2003.8.26.0506. Juiz: Ana Paula Franchito Cypriano. Julgado em: 28 jan. 2008.

30. São Paulo. Tribunal de Justiça do Estado de São Paulo. Apelação. Processo $\mathrm{n}^{\circ}$ 9187357-92.2008.8.26.0000. $8^{\mathrm{a}}$ Câmara de Direito Privado. Ribeirão Preto. Relator: Luiz Ambra. Julgado em: 31 jan. 2012.

31. São Paulo. Tribunal de Justiça do Estado de São Paulo. Apelação. Processo $\mathrm{n}^{\circ}$ 0010653-28.2007.8.26.0451. Piracicaba. Relator: Coelho Mendes. Julgado em: 24 abr. 2012.

32. São Paulo. Tribunal de Justiça do Estado de São Paulo. Ação Rescisória. Processo no 9032583-70.2009.8.26.0000. Ribeirão Preto. Relator: Luiz Ambra. Julgado em: 9 mai. 2012.

33. São Paulo. Tribunal de Justiça do Estado de São Paulo. Apelação. Processo $n^{\circ}$ 0056747-30.2001.8.26.0100. São Paulo. Relator: Salles Rossi. Julgado em: 13 mai. 2012.

34. São Paulo. Tribunal de Justiça do Estado de São Paulo. Apelação. Processo n ${ }^{\circ}$ 0011441-26.2005.8.26.0576. São José do Rio Preto. Relator: Moreira Viegas. Julgado em: 3 out. 2012.

35. São Paulo. Tribunal de Justiça do Estado de São Paulo. Agravo de instrumento. Processo $\mathrm{n}^{\circ}$ 010754603.2012.8.26.0000. São Caetano do Sul. Relator: Ronaldo Andrade. Julgado em: 30 out. 2012.

36. São Paulo. Juízo da $3^{\text {a } V a r a ~ C i ́ v e l ~ d e ~ S a ̃ o ~ C a e t a n o ~ d o ~ S u l . ~}$ Ação de Indenização por Dano Moral. Processo no $0008492-$ 52.2011.8.26.0565. Juiz: Sérgio Noboru Sakagawa. Julgado em: 14 jun. 2012.

37. São Paulo. Tribunal de Justiça do Estado de São Paulo. Embargos de Declaração. Processo $n^{\circ} 0002529$ 64.2010.8.26.0576. São José do Rio Preto. Relator: Lucila Toledo. Julgado em: 26 mar. 2013.

38. São Paulo. Juízo da $4^{a}$ Vara de São José do Rio Preto. Ação de Responsabilidade Civil por Erro Médico. Processo $\mathrm{n}^{\circ}$ 0002529-64.2010.8.26.0576. Juiz: Paulo Sérgio Romero Vicente Rodrigues. Julgado em: 21 mar. 2017

39. São Paulo. Tribunal de Justiça do Estado de São Paulo. Agravo de instrumento. Processo $\mathrm{n}^{\circ}$ 200785863.2014.8.26.0000. São Paulo. Relator: Christine Santini. Julgado em: 26 mar. 2013.

40. São Paulo. Juízo da $33^{\text {a }}$ Vara Cível do Foro Central de São Paulo. Ação de Responsabilidade Civil por Erro Médico. Despacho no Processo $n^{\circ}$ 0124878-71.2012.8.26.0100. Juiz: Douglas Iecco Ravacci. Publicado em: 7 jan. 2014.

41. São Paulo. Tribunal de Justiça do Estado de São Paulo. Apelação. Processo $\mathrm{n}^{\mathrm{o}}$ 0139602-59.2007.8.26.0002. 29a Câmara de Direito Privado São Paulo. Relator: Carlos Henrique Miguel Trevisan. Julgado em: 29 jan. 2015.

42. São Paulo. Tribunal de Justiça do Estado de São Paulo. Apelação. Processo $n^{\circ}$ 0139602-59.2007.8.26.0002. $9^{\text {a }}$ Câmara Direito Privado. São Paulo. Relator: Galdino Toledo Junior. Julgado em: 2 jun. 2015.

43. São Paulo. Tribunal de Justiça do Estado de São Paulo. Embargos de Declaração. Processo $n^{\circ} 0139602-$ 59.2007.8.26.0002. $9^{\text {a }}$ Câmara Direito Privado. São Paulo. Relator: Galdino Toledo Junior. Julgado em: 11 ago. 2015.
44. São Paulo. Tribunal de Justiça do Estado de São Paulo. Agravo de Instrumento. Processo no 904085388.2006.8.26.0000. 8 ${ }^{\text {a }}$ Câmara de Direito Privado. São Paulo. Relator: Silvio Marques Neto. Julgado em: 15 mar. 2006.

45. São Paulo. Tribunal de Justiça do Estado de São Paulo. Embargos de Declaração. Processo $n^{\circ} 0070787$ 75.2005.8.26.0100. 4 ${ }^{\text {a }}$ Câmara de Direito Privado. São Paulo. Relator: Teixeira Leite. Julgado em: 19 set. 2013.

46. São Paulo. Tribunal de Justiça do Estado de São Paulo. Apelação. Processo $n^{0}$ 0070787-75.2005.8.26.0100. 4 ${ }^{\mathrm{a}}$ Câmara de Direito Privado. São Paulo. Relator: Teixeira Leite. Julgado em: 18 jul. 2013.

47. São Paulo. Tribunal de Justiça do Estado de São Paulo. Embargos de Declaração. Processo $\mathrm{n}^{\circ}$ 007078775.2005.8.26.0100. 4 ${ }^{\text {a }}$ Câmara de Direito Privado. São Paulo. Relator: Teixeira Leite. Julgado em: 19 set. 2013.

48. São Paulo. Tribunal de Justiça do Estado de São Paulo. Apelação. Processo $\mathrm{n}^{\mathrm{o}}$ 0016625-81.2007.8.26.0320. $6^{\mathrm{a}}$ Câmara de Direito Privado. Limeira. Relator: Alexandre Lazarini. Julgado em: 6 jun. 2013.

49. São Paulo. Tribunal de Justiça do Estado de São Paulo. Apelação. Processo $\mathrm{n}^{\mathrm{o}}$ 0018226-86.2010.8.26.0007. 9a Câmara de Direito Privado. São Paulo. Relator: José Aparício Prado Neto. Julgado em: 10 mar. 2015.

50. São Paulo. Tribunal de Justiça do Estado de São Paulo. Apelação. Processo $n^{\mathrm{o}}$ 0035661-95.2011.8.26.0053. 11 Câmara de Direito Público. São Paulo. Relator: Marcelo L Theodosio. Julgado em: 9 jun. 2015.

51. São Paulo. Tribunal de Justiça do Estado de São Paulo. Apelação. Processo $\mathrm{n}^{\mathrm{o}}$ 0127580-29.2008.8.26.0100. $3^{\mathrm{a}}$ Câmara Extraordinária de Direito Público. São Paulo. Relator: Beatriz Braga. Julgado em: 29 set. 2015.

52. São Paulo. Tribunal de Justiça do Estado de São Paulo. Apelação. Processo $\mathrm{n}^{\mathrm{o}}$ 0127580-29.2008.8.26.0100. $3^{\text {a }}$ Câmara Extraordinária de Direito Público. São Paulo. Relator: Beatriz Braga. Julgado em: 29 set. 2015. Roberto Martins de Souza. Voto vencido.

53. São Paulo. Tribunal de Justiça do Estado de São Paulo. Apelação. Processo $n^{\circ}$ 0000732-59.2009.8.26.0456. 13 Câmara Extraordinária de Direito Privado. Pirapozinho. Relator: Silvério da Silva. Julgado em: 2 mar. 2016.

54. São Paulo. Tribunal de Justiça do Estado de São Paulo. Apelação. Processo $n^{\mathrm{o}}$ 0127922-49.2008.8.26.0000. 10 Câmara de Direito Privado. Ribeirão Preto. Relator: Cesar Ciampolini. Julgado em: 11 mar. 2016.

55. São Paulo. Tribunal de Justiça do Estado de São Paulo. Apelação. Processo $\mathrm{n}^{\mathrm{o}}$ 0014275-18.2005.8.26.0506. 11 ${ }^{\mathrm{a}}$ Câmara de Direito Público. Ribeirão Preto. Relator: Aroldo Viotti. Julgado em: 5 abr. 2016.

56. São Paulo. Tribunal de Justiça do Estado de São Paulo. Apelação. Processo $n^{0}$ 0023212-86.2003.8.26.0053. $6^{\text {a }}$ Câmara de Direito Público. São Paulo Relator: Sidney Romano dos Reis. Julgado em: 15 abr. 2016.

57. Carvalho M, Vieira AA. Erro médico em pacientes hospitalizados. J Pediatr. 2002;78(4):261-8. DOI: http:// dx.doi.org/10.1590/S0021-75572002000400004

58. Souza NTC. Erro médico e o novo Código Civil. O neófitoInformativo Jurídico [Internet]. 2003 [acesso em 2017 jan. 7]. Disponível em: http://egov.ufsc.br/portal/sites/default/ 
files/anexos/7263-7262-1-PB.pdf

59. Brasil. Supremo Tribunal Federal. Ag. Reg. ${ }^{\circ}$ Recurso Extraordinário n ${ }^{\circ}$ 606.945. Relator: Ministro Teori Zavascki. Julgado em: 30 jun. 2016.

60. Silva JA. Comentário contextual à Constituição. São Paulo: Malheiros; 2005. p.349.

61. Brasil. Supremo Tribunal de Justiça. Recurso Extraordinário $\mathrm{n}^{\circ}$ 327.904. $1^{\text {a }}$ Turma. Relator: Ministro Carlos Britto. Julgado em: 15 ago. 2006.

62. Brasil. Supremo Tribunal Federal. Ag. Reg. $\mathrm{n}^{\circ}$ Recurso Extraordinário com Agravo no 908.331. Relator: Ministro Dias Tofolli. Julgado em: 15 mar. 2016.

63. São Paulo. Tribunal de Justiça do Estado de São Paulo. Apelação. Processo $\mathrm{n}^{\mathrm{o}}$ 0008036-31.2009.8.26.0482. $7^{\mathrm{a}}$ Câmara de Direito Público. Relator: Magalhães Coelho. Julgado em: 23 fev. 2015.

64. Brasil Presidência da República, Casa Civil, Subchefia para Assuntos Jurídicos. Lei n ${ }^{\circ}$ 13.105, de 16 de março de 2015. Código de Processo Civil [Internet]. Brasília, DF; 2015 [acesso em 2017 jan. 7]. Disponível em: www.planalto.gov. br/ccivil_03/_ato2015-2018/2015/1ei/113105.htm

65. Brasil. Superior Tribunal de Justiça. Embargos de Divergência em Recurso Especial $n^{\circ}$ 313886. Relatora: Ministra Eliana Calmon. Julgado em 24/02/2004.

66. São Paulo. Tribunal de Justiça do Estado de São Paulo. Agravo de Instrumento $\mathrm{n}^{\mathrm{o}}$ 2085047-49.2016.8.26.0000.
Relatora: Desembargadora Daise Fajardo Nogueira Jacob. Julgado em 4/10/2016.

67. Brasil. Superior Tribunal de Justiça. Recurso Especial $\mathrm{n}^{0}$ 1.165.279. Relator: Ministro Paulo de Tarso Sanseverino. Julgado em: 22 mai. 2012.

68. Brasil. Superior Tribunal de Justiça. Recurso Especial no 316.283. Relator: Ministro Ruy Rosado de Aguiar. Julgado em: 18 jan. 2001.

69. Studdert DM, Mello MM, Gawande AA, Gandhi TK, Kachalia A, Yoon C, et al. Claims, errors, and compensation payments in medical malpractice litigation. N Engl J Med. 2006;354(19):2024-33.

70. Brasil. Conselho Federal de Medicina. Resolução $\mathrm{n}^{0}$ 1.931, 24 de setembro de 2009. Aprova o Código de Ética Médica [Internet]. Brasília, DF; 2009 [acesso em 2017 jul. 5]. Disponível em: http://www.portalmedico.org.br/ novocodigo/integra.asp

71. São Paulo. Lei no 10.241 , de 17 de março de 1999. Dispõe sobre os direitos dos usuários dos serviços e das ações de saúde no Estado e dá outras providências [Internet]. São Paulo; 1999 [acesso em 2017 jan. 7]. Disponível em: http:// www.pge.sp.gov.br/centrodeestudos/bibliotecavirtual/dh/ volume $\% 20 \mathrm{i} /$ saudelei10241.htm

72. Brasil. Superior Tribunal de Justiça. Recurso Especial $n^{\circ}$ 1.208.949. Relatora: Ministra Nancy Andrighi. $3^{\mathrm{a}}$ Turma. Julgado em: 15 dez. 2010. 